\title{
MODEL EDUKASI BERDASARKAN SEGMENTASI KONSUMEN UNTUK MEMBANGUN MINAT MASYARAKAT PADA PERBANKAN SYARIAH
}

\author{
Bambang Waluyo, Sylvia Rozza, dan Sujarwo \\ Jurusan Akuntansi Politeknik Negeri Jakarta, Kampus Universitas Indonesia, Depok 16421 \\ E-mail: bamwaluyo13@gmail.com
}

\begin{abstract}
ABSTRAK, Pemahaman masyarakat yang rendah terhadap perbankan syariah menjadi tantangan tersendiri dalam pengembangan perbankan syariah di Indonesia. Tujuan penelitian mengetahui variasi pelaku segmentasi konsumen dengan memperhatikan aspekaspek kognitif, sosial, emosional, fisik, estetika dan spiritual. Metode penelitian adalah deskriptif kualitatif. Penelitian terdahulu menemukan lima segmen konsumen yaitu syariah loyalis, obligatory, follower, functional benefit, dan essentially conventional. Ranking pemahaman terhadap perbankan syariah berdasarkan urutan dari yang paling paham hingga yang paling tidak paham adalah syariah loyalis, obligatory, follower, functional benefit dan essentially conventional. Dasar yang dapat digunakan dalam edukasi perbankan syariah adalah : (1). edukasi perbankan syariah masih sangat diperlukan, (2). Edukasi perbankan syariah perlu dimasukkan dalam kurikulum sekolah, (3). Informasi tentang bank syariah dapat disampaikan melalui iklan pada berbagai media, dan (4). Segmen essentially conventional perlu diberi edukasi baik tentang produk maupun tentang perbankan syariah itu sendiri. Kerjasama diantara para stakeholders sangat diperlukan dalam edukasi perbankan syariah. Evaluasi keberhasilan edukasi dapat dilihat dari meningkatnya awareness segmen essentially conventional pada perbankan syariah.
\end{abstract}

Kata kunci: model edukasi; segmentasi konsumen; minat masyarakat; perbankan syariah

\section{CONSUMERS SEGMENTATION BASED EDUCATION MODEL IN BUILDING SOCIETY'S INTEREST IN ISLAMIC BANKING}

\begin{abstract}
Lack of society's understandings in Islamic banking is a challenge in Islamic banking development in Indonesia. This research is aimed at knowing all behaviour varieties in consumers segmentation based sharia banking education model which focuses on cognitive, social, emotional physical aesthetics, and spiritual aspects. This is a qualitative research. The prior research had founds five segments of customer, i.e. syariah loyalis, obligatory, follower, functional benefit, and essentially conventional. The ranking of understanding of sharia banking made from the most understand to the least understand is the segment of sharia loyalist, obligatory, follower, functional benefit, and essentially conventional. Some basic thoughts that can be used in Islamic banking education are: (1). Education on sharia banking is still needed to provide understanding to the community about sharia banking, (2). Sharia banking education should be included in the school curriculum, (3). Information about sharia banking can be broadcasted in various advertising media, and (4). The essentially conventional segmen should be given a more intensive education about sharia banking both on products and sharia banking institutions. There must be collaboration among all stakeholders for education on sharia banking. Evaluation of public education success can increasing awareness of essentially conventional segment toward sharia banking.
\end{abstract}

Key words: education model; consumers segmentation; society interest; shria banking

\section{PENDAHULUAN}

Pemahaman masyarakat yang rendah terhadap perbankan syariah menjadi tantangan dalam upaya pengembangan perbankan syariah. Kepala Departemen Perbankan Syariah Bank Indonesia (BI), Edy Setiadi, mengatakan bahwa upaya meningkatkan pemahaman dan preferensi masyarakat menggunakan perbankan syariah merupakan salah satu tantangan dalam pengembangan perbankan syariah (http ://ekonomisyariah.info). Dalam sambutannya pada pencanangan Gerakan Ekonomi Syariah (GRES), Presiden Susilo Bambang Yudhoyono menyebutkan bahwa sosialisasi dan edukasi masyarakat menjadi tantangan dalam mengakselerasi pertumbuhan keuangan syariah (Setkab Republik Indonesia, 2013). Perbankan Indonesia belum memiliki program edukasi yang memadai, komprehensif, terintegrasi dan terencana dengan baik dalam rangka meningkatkan pemahaman masyarakat di bidang keuangan khususnya perbankan (Bank Indonesia, 2007 (1)). Langkah nyata upaya pengem- bangan perbankan syariah dilakukan BI di mana pada 2013 merumuskan Grand Strategi Pengembangan Pasar Perbankan Syariah. Grand strategi tersebut merupakan strategi komprehensif pengembangan pasar meliputi aspek strategis antara lain program sosialisasi dan edukasi masyarakat secara lebih luas dan efisien melalui berbagai sarana komunikasi langsung, maupun tidak langsung (media cetak, elektronik, online/web-site), yang bertujuan memberikan pemahaman tentang kemanfaatan produk serta jasa perbankan syariah bagi masyarakat. Perkembangan terkini tentang edukasi perbankan syariah terdapat dalam cetak Biru Pengembangan, yang pada salah satu pilarnya adalah pada Penguatan Riset, Asesmen dan Edukasi, di mana Bank Indonesia akan memaksimalkan dalam memperkuat riset dan asesmen ekonomi syariah; meningkatkan kompetensi industri dan regulator; dan peningkatan awareness masyarakat (Bank Indonesia, 2018). Dengan demikian dari sisi edukasi saat ini adalah dalam proses penguatan agar masyarakat semakin memahami perbankan syariah baik dari sisi kelembagaan 
maupun hak dan kewajibam masyarakat sebagai pengguna jasa perbankan. Upaya pengembangan ekonomi dan keuangan syariah terus dilakukan hingga saat ini, tidak dapat dijalankan secara parsial (Bank Indonesia, 2017). Peran riset, asesmen, edukasi serta kerjasama yang erat antar institusi menjadi bagian integral yang tidak dapat dipisahkan dan semakin dibutuhkan dalam menjalankan strategi dan program sehingga lebih efektif.

Hirsanuddin (2005) menyatakan bahwa untuk meningkatkan pemahaman masyarakat terhadap prinsip operasional perbankan syariah, maka perlu dilakukan sosialisasi yang intensif oleh pihak bank sendiri, BI, pemerintah dan pihak-pihak yang terkait. Winandar (2011) juga menyebutkan bahwa strategi komunikasi dan sosialisasi yang dilakukan BI masih belum efektif sampai kepada masyarakat sehingga bank syariah masih dikenal eksklusif untuk umat Islam Indonesia. Istilah-istilah dalam perbankan syariah harus disosialisaikan seperti istilah bagi hasil. Bagi hasil (profit and loss sharing) di bank syariah dapat dibedakan dengan sistem bunga (interest) di bank konvensional dalam setiap transaksinya (Bachro, 2010).

Strategi yang jitu dan ampuh dalam memasarkan bank syariah yang hingga kini belum ditemukan oleh BI dan bank-bank syariah, juga menjadi faktor penyebab masyarakat belum berhubungan dengan bank syariah (Rahmad, 2015). Waluyo dan Ekowati (2008) dalam penelitiannya menemukan bahwa mayoritas responden menyatakan istilah-istilah dalam laporan keuangan bank syariah sulit dimengerti karena baru mengetahui istilahistilah tersebut (misalnya murabahah) yang menyebabkan nama produk pada bank syariah tidak familiar. Waluyo dan Ansori (2010) menemukan alasan masyarakat tidak memilih bank syariah antara lain karena belum kenal dengan produk syariah, sosialisasi yang kurang, informasi yang terbatas tentang kelebihan menjadi nasabah bank syariah, tidak ada yang memberikan informasi lebih dalam tentang bank syariah. Waluyo dan Waluyo (2013) juga menemukan masih terjadi mispersepsi masyarakat terhadap perbankan syariah yang ditandai dengan masih besarnya persentase responden yang menganggap margin dalam murabahah (jual beli) di bank syariah merupakan istilah lain dari bunga/riba yang digunakan di bank konvensional, serta istilah-istilah pada perbankan syariah sulit dipahami. Dalam suatu komunikasi, pesan yang disampaikan belum tentu diterima dengan benar sesuai dengan yang dimaksud peneriman pesan (Daniar dan Syam, 2012). Waluyo dan Sujarwo (2013) mengemukakan bahwa dalam sosialisasi dan edukasi publik perbankan syariah perlu dilakukan beberapa usaha yaitu jangkauan edukasi diperluas misalnya target kelompok masyarakat yang dituju maupun media yang digunakan dalam pelaksanaan edukasi tersebut.

Hasil penelitian terdahulu tersebut menunjukkan penyebab masyarakat belum memahami perbankan syariah adalah karena strategi edukasi dan komunikasi yang belum efektif sampai kepada masyarakat sehingga masyarakat tidak memahami istilah-istilah dalam perbankan syariah, belum kenal dengan produk perbankan syariah bahkan terjadi mispersepsi terhadap perbankan syariah. Hal-hal tersebut dapat berpengaruh terhadap minat masyarakat pada perbankan syariah. Untuk mengatasi kelemahan yang ada pada edukasi yang telah dilakukan, perlu dilakukan sesuatu yang baru dalam proses edukasi perbankan syariah.

Edukasi perbankan syariah yang dilakukan dengan memperhatikansegmentasi konsumen banksyariah diharapkan hasilnya akan optimal. Edukasi terhadap segmen syariah loyalis harus dibedakan dengan edukasi terhadap segmen essentially conventional. Riset pengembangan pasar yang dilakukan oleh BI bersama MarkPlus.co menghasilkan pemetaan segmentasi konsumen bank syariah berdasarkan orientasi bank dibagi berdasarkan segmen sebagai berikut (Bank Indonesia, 2012):

a. Syariah Loyalis yaitu segmen pokoknya syariah yang dalam kondisi apapun akan menggunakan bank syariah.

b. Follower, yaitu segmen ikut-ikutan yang akan menggunakan bank syariah jika orang lain menggunakannya.

c. Functional Benefit, yaitu segmen yang akan menggunakan bank syariah, ataupun bank konvensional tergantung fungsi atau kegunaan.

d. Obligatory, yaitu segmen yang terpaksa menggunakan jasa perbankan syariah karena sesuatu hal misalnya menerima gaji atau pembayaran transaksi harus melalui bank syariah.

e. Essentially Conventional, yaitu segmen pokoknya konvensional yang dalam kondisi apapun hanya menggunakan bank konvensional.

Edukasi perbankan syariah juga harus memperhatikan aspek kognitif, sosial, emosional, estetika dan spiritual. Oleh karena itu perlu dibuat model edukasi perbankan syariah yang mengintegrasikan segmen konsumen dengan memperhatikan aspek-aspek kognitif, sosial, emosional, estetika dan spiritualnya. Perhatian terhadap aspek-aspek kognitif diperlukan mengingat pemahaman masyarakat terhadap perbankan syariah masih rendah sehingga perlu penyampaian informasi perbankan syariah dengan logis dan mudah diterima masyarakat. Pada aspek sosial perlu diperhatikan bahwa masyarakat sasaran adalah berada pada lapisan sosial yang berbeda-beda. Aspek emosional perlu ditekankan bahwa semua pembelajaran dalam edukasi selayaknya juga memperhatikan keadaan untuk dapat membangkitkan rasa memiliki terhadap bank syariah. Aspek estetika perlu memperhatikan hal-hal yang menjadikan proses edukasi lebih menarik. Aspek spiritual adalah bahwa edukasi perlu mendasarkan pada penekanan bank syariah adalah bank yang beroperasi sesuai syariah Islam namun bersifat universal untuk seluruh umat manusia tanpa batas-batas keyakinan terhadap ajaran agama. Empat komponen utama dari model ini adalah fondasi/dasar, organisasi, 
pelaksanaan, dan evaluasi (Retallick dan Miller, 2010). Model edukasi tersebut diharapkan menjadi sesuatu yang baru dan mendukung kebijakan edukasi dan sosialisasi perbankan syariah.

Minat masyarakat pada perbankan syariah perlu menjadi perhatian para stakeholders khususnya pelaku industri perbankan syariah dan pihak regulator (Otoritas Jasa Keuangan/OJK). Minat masyarakat mulai meningkat yang ditunjukkan dengan jumlah rekening dana pihak ketiga di bank syariah yang terus meningkat. OJK berupaya menjalankan program strategis terutama menyangkut optimalisasi promosi keuangan syariah untuk mening-katkan literasi dan preferensi masyarakat dalam rangka mengembangkan keuangan syariah. Peningkatan min0,8at masyarakat terhadap perbankan syariah harus dijadikan motivasi untuk terus melakukan inovasi produk yang dapat memenuhi kebutuhan masyarakat serta langkah-langkah alternatif pemberian edukasi kepada masyarakat agar edukasi menjadi mudah diterima oleh masyarakat yang heterogen.

\section{METODE}

Penelitian ini adalah penelitian deskriptif kualitatif dengan data primer, dikumpulkan melalui instrument kuesioner, untuk memetakan segmentasi konsumen dan pemahamannya terhadap perbankan syariah serta model edukasi. Pengukuran variabel penelitian dilakukan dengan menghitung persentase jawaban responden pada masingmasing pertanyaan. Unit analisi adalah masyarakat di wilayah Jabodetabek. Pemilihan wilayah Jabodetabek adalah karena masyarakat pada wilayah tersebut dianggap mampu mencerminkan variasi sosial, pendidikan dan kehidupan ekonominya. Rancangan model edukasi akan mengadopsi model yang dikemukakan oleh Rettalick dan Miller (2010) yaitu Early Field Experiences (EFE). Model edukasi yang dibuat juga memperhatikan MultiDimensional Perspectives of Holistic Education yang dikemukakan Nava (2010). Populasi penelitian adalah masyarakat di wilayah Jabodetabek yaitu kelompok pelajar, kelompok mahasiswa, kelompok professional, kelompok lembaga penunjang perekonomian (termasuk penegak hukum dan instansi pemerintah terkait) dan kelompok lain-lain (termasuk ibu rumah tangga, sektor informal, dan sebagainya). Teknik pengambilan sampel adalah accidental sampling. Jumlah sampel pada penelitian ini adalah 200 responden. Jumlah tersebut berdasarkan pada apa yang disampaikan Sukardi (2004), bahwa dengan menggunakan rumus tertentu Isaac dan Michael memberikan hasil akhir jumlah sampel terhadap jumlah populasi antara $10-100.000$. Data diolah dengan program SPSS. Kuesioner dengan jawaban "ya" diberi bobot 3, "ragu-ragu" bobot 2, dan "tidak" bobot 1 . Uji validitas (uji kesahihan) digunakan untuk mengukur valid tidaknya kuesioner.

\section{HASIL DAN PEMBAHASAN}

\section{Segmentasi Konsumen}

Responden dalam penelitian ini berjumlah 200 orang di wilayah Jakarta, Bogor, Depok, Tangerang dan Bekasi. Berikut adalah potret responden menurut segmentasiya:

\section{Tabel 1. Segmen Responden}

\begin{tabular}{lrr}
\hline \multicolumn{1}{c}{ Segmentasi } & Jumlah & Persentase \\
\hline a. Syariah Loyalis & 12 & $6 \%$ \\
b. Follower & 3 & $2 \%$ \\
c. Functional Benefit & 151 & $76 \%$ \\
d. Obligatory & 9 & $5 \%$ \\
e. Essentially Conventional & 25 & $13 \%$ \\
\hline \multicolumn{2}{c}{ Total } & 200 \\
\hline & Sumber : Data Diolah, 2017
\end{tabular}

Mayoritas responden merupakan segmen functional benefit, sedangkan segmen follower merupakan segmen yang paling sedikit dibandingkan dengan yang lain.

\section{Data Pemahaman Tentang Bank Syariah}

Berikut ini adalah data yang diperoleh mengenai pemahaman masyarakat terhadap perbankan syariah.

\section{a) Bagi Hasil-Mudharabah}

Segmen syariah loyalis, 75 \% menyatakan memahami istilah mudharabah yang ada di bank syariah. Segmen follower terbagi rata antara yang pernah, ragu dan tidak memahami istilah mudharabah yang ada di bank syariah. Segmen functional benefit memiliki pendapat yang relatif tersebar antara yang paham, ragu dan tidak paham istilah bagi hasil-mudharabah dimana $35,76 \%$ menyatakan memahami, $21,19 \%$ ragu dan $41,72 \%$ menyatakan tidak memahami istilah bagi hasil-mudharabah. Segmen obligatory mayoritas yaitu $55,56 \%$ menyatakan tidak memahami istilah bagi hasil-mudharabah. Demikian juga segmen essentialy conventional dimana $72 \%$ menyatakan tidak memahami istilah bagi hasil-mudharabah.

\section{b). Jual beli-murabahah}

Segmen syariah loyalis, 66,67\% menyatakan memahami istilah murabahah yang ada di bank syariah. Segmen follower terbagi rata antara yang pernah, ragu dan tidak memahami istilah murabahah yang ada di bank syariah. Segmen functional benefit memiliki pendapat yang relatif tersebar antara yang paham, ragu dan tidak paham istilah murabahah dimana 23,84\% menyatakan memahami, $25,17 \%$ ragu dan 46,36\% menyatakan tidak memahami istilah murabahah. Segmen obligatory masih mayoritas yaitu 66,67\% menyatakan tidak memahami istilah murabahah. Demikian juga dengan segmen essentialy conventional dimana $76 \%$ menyatakan tidak memahami istilah murabahah.

\section{c). Sewa menyewa-ijarah}

Segmen syariah loyalis 58,33\% menyatakan memahami istilah ijarah yang ada di bank syariah. 
Segmen follower terbagi rata antara yang pernah, ragu dan tidak memahami istilah ijarah yang ada di bank syariah. Segmen functional benefit mayoritas 52,32\% menyatakan tidak memahami istilah ijarah. Segmen obligatory juga mayoritas yaitu $66,67 \%$ menyatakan tidak memahami istilah ijarah. Segmen essentialy conventional $84 \%$ menyatakan tidak memahami istilah murabahah.

Berdasarkan data di atas maka dapat dibuat ranking pemahaman terhadap perbankan syariah jika dibuat urutan dari yang paling paham hingga yang paling tidak paham adalah :

1. Segmen Syariah Loyalis

2. Segmen Obligatory

3. Segmen Follower

4. Segmen Functional benefit

5. Segmen Essentially conventional

Segmen essentially conventional terlihat sebagai segmen yang paling tidak paham terhadap perbankan syariah. Hal tersebut karena segmen essentially conventional merupakan segmen yang tidak pernah menerima informasi tentang perbankan syariah. Segmen syariah loyalis, obligator, follower dan functional benefit pernah menerima informasi tentang perbankan syariah namun hanya segmen syariah loyalis yang memahami istilahistilah yang ada di bank syariah: bagi hasil-mudharabah, jual beli-murabahah, dan sewa menyewa-ijarah.

\section{Data Model Edukasi Perbankan Syariah Berdasarkan Segmen Konsumen}

Berikut ini adalah data yang diperoleh mengenai model edukasi perbankan syariah:

1. Informasi Tentang Bank Syariah Sebaiknya Disisipkan Melalui Ceramah Umum Seperti Melalui Pengajian. Responden yang termasuk dalam segmen syariah loyalis, mayoritas yaitu 91,67\% menyatakan informasi tentang bank syariah sebaiknya disisipkan melalui ceramah umum seperti melalui pengajian. Demikian juga pada segmen functional benefit, obligatory dan essentially conventional secara mayoritas berpendapat sebaiknya informasi tentang bank syariah disisipkan melalui ceramah umum seperti melalui pengajian.

2. Informasi Tentang Bank Syariah Sebaiknya Dimasuk-kan Dalam Materi Khutbah Jumat.

Responden yang termasuk dalam segmen syariah loyalis, obligatory dan essentially conventional secara mayoritas menyatakan informasi tentang bank syariah sebaiknya dimasukkan dalam materi khutbah jumat. Pada segmen follower terbagi rata antara yang berpendapat sebaiknya, ragu dan tidak perlu informasi tentang bank syariah dimasukkan dalam materi khutbah jumat. Pada segmen functinal benefit pun tersebar hampir merata diantara yang berpendapat sebaiknya (39\%), ragu $(31,79 \%)$ dan tidak perlu $(28,48 \%)$ informasi tentang bank syariah dimasukkan dalam materi khutbah jumat.
3. Informasi Tentang Bank Syariah Sebaiknya Secara Gencar Dilakukan Melalui Iklan Di Media Massa (Koran, Majalah, dan lain-lain).

Semua segmen syariah loyalis, follower, functional benefit, obligatory dan essentially conventional secara mayoritas menyatakan Informasi tentang bank syariah sebaiknya secara gencar dilakukan melalui iklan di media massa (koran, majalah, dan lain-lain).

4. Informasi Tentang Bank Syariah Sebaiknya Secara Gencar Dilakukan Melalui Iklan Di Media Elektronik ( $\mathrm{TV}$, radio).

Semua segmen syariah loyalis, follower, functional benefit, obligatory dan essentially conventional secara mayoritas menyatakan Informasi tentang bank syariah sebaiknya secara gencar dilakukan melalui iklan di media elektronik (tv, radio).

5. Informasi Tentang Bank Syariah Sebaiknya Juga Dilakukan Melalui Iklan Di Media Sosial (Facebook, Twitter, dan lain-lain).

Semua segmen syariah loyalis, follower, functional benefit, obligatory dan essentially conventional secara mayoritas menyatakan informasi tentang bank syariah sebaiknya juga dilakukan melalui iklan di media sosial (facebook, twitter, dan lain-lain).

6. Kesediaan Memindahkan Rekening Bank Konvensional Ke Bank Syariah Jika Memahami Apa Itu Bank Syariah.

Segmen syariah loyalis, functional benefit, dan obligatory secara mayoritas menyatakan kesediaan memindahkan rekening di bank konvensional ke bank syariah jika memahami tentang bank syariah. Segmen follower seluruhnya ragu memindahkan rekening di bank konvensional ke bank syariah walaupun mereka nantinya memahami tentang bank syariah.

7. Informasi Tentang Bank Syariah Seharusnya Masuk Dalam Kurikulum Sekolah

Hanya segmen syariah loyalis dan follower yang mayoritas menyatakan informasi tentang bank syariah seharusnya masuk dalam kurikulum sekolah. Walaupun belum sampai di atas 50\%, namun persetujuan segmen functional benefit, obligatory dan essentialy conventional bahwa informasi tentang bank syariah seharusnya masuk dalam kurikulum sekolah masih lebih tinggi dibandingkan yang ragu dan tidak perlu bahwa informasi tentang bank syariah seharusnya masuk dalam kurikulum sekolah.

8. Perubahan Cara Pandang Terhadap Bank Syariah Jika Menerima Edukasi Bank Syariah

Segmen syariah loyalis, follower, functional benefit, obligatory secara mayoritas menyatakan akan mengubah cara pandang terhadap bank syariah jika menerima edukasi tentang bank syariah. Pada sisi segmen nasabah, segmen essentially conventional hanya $44 \%$ yang menyatakan akan mengubah cara pandang terhadap bank syariah jika menerima edukasi tentang bank syariah, 48\% menyatakan ragu, dan $8 \%$ tidak akan mengubah 
cara pandang terhadap bank syariah jika menerima edukasi tentang bank syariah.

9. Mencoba Menggunakan Bank Syariah Dalam Transaksi Perbankan, Jika Menerima Edukasi Tentang Bank Syariah.

Semua segmen mayoritas menyatakan akan mencoba menggunakan bank syariah dalam transaksi perbankan jika menerima edukasi tentang bank syariah. Bagi segmen syariah loyalis sangat wajar 100\% menyatakan akan mencoba menggunakan bank syariah dalam transaksi perbankanjika menerima edukasi tentang bank syariah. Namun hal tersebut dapat juga dapat dipahami bahwa mereka pun siap mencoba menggunakan produk perbankan selain yang selama ini mereka gunakan. Pada segmen essentially conventional, sebanyak 68\% (lebih tinggi dibandingkan dengan segmen follower, fuctional benefit dan obligatory) menyatakan akan mencoba menggunakan bank syariah dalam transaksi perbankan jika menerima edukasi tentang bank syariah.

\section{Model Edukasi Perbankan Syariah Berdasarkan Segmentasi Konsumen}

Rancangan model edukasi mengadopsi model yang dikemukakan oleh Rettalick dan Miller (2010) yaitu Early Field Experiences (EFE). Model ini menyediakan struktur untuk mengembangkan berbagai pengalaman lapangan awal dengan tetap menjaga kesinambungan antara program dan memungkinkan adanya keragaman budaya dan fleksibilitas individu. Oleh karena itu model yang akan dibuat juga akan memperhatikan dasar dalam melakukan edukasi, pengorganisasian, pelaksanaan hingga evaluasi edukasi perbankan syariah. Model edukasi menjadi masukan kepada pihak stakeholders (industri bank syariah, pemerintah, Bank Indonesia, Otoritas Jasa Keuangan) dalam membuat kebijakan edukasi publik.

\section{Fondasi/Dasar}

Dasar yang akan dijadikan untuk merancang model edukasi adalah potret segmentasi konsumen serta data pemahaman dan model edukasi yang diinginkan oleh responden sebagai representasi konsumen/masyarakat. Berdasarkan data yang diperoleh, dapat dikemukakan hal-hal pokok yang dapat menjadi dasar dalam melakukan edukasi terhadap bank syariah dan model edukasi sesuai dengan segmen konsumen/masyarakat.

\section{a. Aspek Kognitif}

Aspek kognitif dilihat dari sisi pernah atau tidak menerima edukasi tentang perbankan syariah. Ditinjau dari pernah atau tidak menerima edukasi tentang perbankan syariah, hanya segmen syariah loyalis yang mayoritas pernah menerima edukasi tentang perbankan syariah, segmen lainnya mayoritas belum pernah menerima edukasi. Oleh karena itu, dapat disimpulkan bahwa edukasi meng-enai perbankan syariah masih sangat diperlukan. Hal tersebut juga dapat dikaitkan dengan rendahnya pemahaman masyarakat terhadap perbankan syariah, di mana masyarakat mayoritas tidak pernah mendengar dan tidak memahami istilah-istilah yang ada di bank syariah. Ketidakpahaman masyarakat terhadap perbankan syariah harus segera diatasi dengan memberikan edukasi yang terus menerus dengan melibatkan berbagai pihak yang berkepentingan (stakeholders).

b. Aspek Sosial

Informasi tentang bank syariah sebaiknya masuk dalam kurikulum sekolah. Responden dalam kategori syariah loyalis dan follower mayoritas menyatakan informasi tentang bank syariah sebaiknya masuk dalam kurikulum sekolah. Demikian juga dengan segmen functional benefit, obligatory dan essentialy conventional walaupun belum sampai di atas 50\%, namun persetujuan bahwa informasi tentang bank syariah sebaiknya masuk dalam kurikulum sekolah masih lebih tinggi dibandingkan yang ragu dan tidak perlu informasi tentang bank syariah sebaiknya masuk dalam kurikulum sekolah.

Bank syariah punya nilai keunggulan tersendiri dibandingkan dengan bank konvensional. Segmen syariah loyalis, follower, functional benefit, obligatory secara mayoritas menyatakan bank syariah punya nilai keunggulan tersendiri dibandingkan dengan bank konvensional. Walaupun pada segmen essentially conventional masing-masing berjumlah sama yaitu 48\% antara yang setuju dan ragu bahwa bank syariah mempunyai nilai keunggulan tersendiri dibandingkan bank konvensional, namun masih dapat dikatakan bahwa bank syariah sesungguhnya mempunyai nilai-nilai keunggulan tersendiri daripada bank konvensional. Pernyataan bahwa bank konvensional memiliki produk yang lebih unggul dibandingkan dengan bank syariah, secara umum diragukan oleh semua segmen, bahkan pada segmen essentialy conventional yang merupakan segmen "harus ber-bank konvensional" hanya 36\% yang menyatakan bahwa bank konvensional mempunyai produk yang lebih unggul dibandingkan dengan produk bank syariah. Berdasarkan aspek sosial, dapat disimpulkan bahwa edukasi perbankan syariah:

1). Harus dimasukkan dalam kurikulum sekolah.

2). Segmen essentially conventional perlu diprioritaskan agar dapat memahami bahwa bank syariah punya nilai keunggulan tersendiri dibandingkan dengan bank konvensional.

\section{c. Aspek Emosional.}

Semua sepakat bahwa edukasi bank syariah seharusnya mengedepankan aspek membangkitkan rasa memiliki terhadap bank syariah (emosional). Semua segmen syariah loyalis, follower, functional benefit, obligatory dan essentially conventional mayoritas menyatakan edukasi bank syariah seharusnya 
mengedepankan aspek membangkitkan rasa memiliki terhadap bank syariah (emosional).

Segmen syariah loyalis, follower, functional benefit, obligatory secara mayoritas menyatakan akan mengubah cara pandang terhadap bank syariah jika menerima edukasi tentang bank syariah. Pada segmen essentially conventional hanya $8 \%$ yang menyatakan tidak akan mengubah cara pandang terhadap bank syariah jika menerima edukasi tentang bank syariah, sedangkan secara mayoritas menyatakan setuju dan ragu. Semua segmen mayoritas menyatakan akan mencoba menggunakan bank syariah dalam transaksi perbankan jika menerima edukasi tentang bank syariah. Segmen syariah loyalis, follower, functional benefit dan essentially conventional secara mayoritas menyatakan kesediaan memindahkan rekening yang ada di bank konvensional ke bank syariah jika memahami apa itu bank syariah.

Berdasarkan aspek emosional, dapat disimpulkan bahwa :

1). Masyarakat akan mengubah cara pandang terhadap bank syariah jika menerima edukasi tentang bank syariah.

2). Masyarakat menyatakan akan mencoba menggunakan bank syariah dalam transaksi perbankan jika menerima edukasi tentang bank syariah.

3). Masyarakat menyatakan kesediaan memindahkan rekening di bank konvensional ke bank syariah jika memahami tentang bank syariah.

\section{d. Aspek Estetika/Keindahan.}

Semua segmen syariah loyalis, follower, functional benefit, obligatory dan essentially conventional mayoritas menyatakan edukasi bank syariah seharusnya mengedepankan aspek estetika/keindahan. Informasi tentang bank syariah sebaiknya secara gencar dilakukan melalui iklan di media massa (koran, majalah dan lain-lain). Semua segmen syariah loyalis, follower, functional benefit, obliga-tory dan essentially conventional secara mayoritas menyatakan informasi tentang bank syariah sebaiknya secara gencar dilakukan melalui iklan di media massa (koran, majalah, dan lain-lain), media elektronik (TV, radio), media sosial (facebook, twitter dll) dan dilakukan secara terusmenerus.

e. Aspek Spiritual/Keagamaan.

Hampir semua segmen, kecualifollower, menyatakan informasi tentang bank syariah sebaiknya disisipkan melalui ceramah umum seperti melalui pengajian. Hal tersebut tentu wajar mengingat pada event pengajian banyak berkumpul umat muslim sehingga informasi yang diberikan akan dapat lebih mengena sasaran dengan harapan akan mampu mengajak masyarakat muslim mau ber-bank syariah.

Informasi tentang bank syariah sebaiknya dimasukkan dalam materi khutbah jumat. Semua segmen syariah loyalis, obligatory dan essentially conventional secara mayoritas menyatakan informasi tentang bank syariah sebaiknya dimasukkan dalam materi khutbah jumat.

Berdasarkan aspek spiritual, dapat disimpulkan :

1). Informasi tentang bank syariah sebaiknya disisipkan melalui ceramah umum seperti melalui pengajian.

2). Informasi tentang bank syariah sebaiknya dimasukkan dalam materi khutbah jumat.

Berdasarkan pembahasan di atas, maka dasar yang dapat digunakan dalam edukasi perbankan syariah adalah:

1). Edukasi mengenai perbankan syariah masih sangat diperlukan untuk memberikan pemahaman kepada masyarakat mengenai perbankan syariah.

2). Edukasi perbankan syariah harus dimasukkan dalam kurikulum sekolah.

3). Iklan dapat digunakan sebagai sarana edukasi tentang bank syariah yang dapat ditayangkan melalui berbagai media.

4). Segmen essentially conventional perlu diberikan edukasi yang lebih intensif tentang perbankan syariah baik mengenai produk maupun lembaga perbankan syariah.

\section{Organisasi}

Edukasi untuk memberikan pemahaman kepada masyarakat tentang keuangan harus menjadi perhatian bagi seluruh pemangku kepentingan (stakeholders) industri keuangan di Indonesia. Upaya memberikan pemahaman kepada masyarakat tentang perbankan syariah harus dilakukan oleh seluruh stakeholders perbankan syariah, baik dengan cara bekerja sama di antara stakeholders maupun secara individual per institusi perbankan syariah. Strategi yang tepat dalam edukasi perbankan syariah akan mempercepat laju pemahaman masyarakat terhadap perbankan syariah.

Dalam menjalankan edukasi publik kepada masyarakat, perlu dilakukan dengan melakukan koordinasi di antara semua pihak yang terlibat dalam edukasi publik bank syariah. Edukasi mengenai perbankan syariah bukanlah hanya tanggung jawab pihak bank syariah saja, namun perlu ada keterlibatan pihak lain. Para pemangku kepentingan dalam edukasi publik perlu berkolaborasi. Di antara para pihak yang dapat terlibat selain pihak bank itu sendiri adalah regulator dan masyarakat. Semua pihak yang terlibat dapat membuat perencanaan bersama untuk terselenggaranya edukasi publik yang efisien dan efektif. Unsur regulator diwakili oleh OJK dan unsur masyarakat dapat diwakili oleh lembaga/ organisisasi pemerhati ekonomi Islam misalnya Pusat Komunikasi Ekonomi Syariah (PKES), Dewan Syariah Nasional (DSN), Masyarakat Ekonomi Syariah (MES), Ikatan Ahli Ekonomi Islam Indonesia (IAEI), lembaga pendidikan, Dewan Syariah Nasional (DSN), dan Asosiasi Bank Syariah Indonesia (Asbisindo). 


\section{Pelaksanaan}

Dalam pelaksanaan edukasi publik, masing-masing pihak diharapkan tidak berjalan sendiri namun ada aliansi di antara mereka yang terlibat dalam edukasi. Aliansi dalam edukasi perbankan syariah dapat diartikan sebagai sebuah kerja sama jangka panjang antar berbagai pihak yang terlibat dalam edukasi publik.

Dalam intensifikasi edukasi publik dan aliansi mitra strategis, kegiatannya adalah (Bank Indonesia, 2007

(2)).

a. Mengadakan kerjasama dengan pihak ketiga (antara lain public figures, bank syariah, PKES) untuk sosialisasi perbankan syariah.

b. Mengadakan aliansi dengan Majelis Ulama Indonesia (MUI) dan lembaga lainnya (seperti Perguruan Tinggi, lembaga training) untuk menyampaikan pesan terkait dengan perbankan syariah.

c. Menyelenggarakan Pasar Rakyat Syariah yang menghadirkan perbankan syariah dan berbagai usaha yang telah mendapatkan sertifikasi halal serta hiburan kepada masyarakat

d. Iklan layanan masyarakat secara masal dengan mengundang public figure, variety talk show, live show on TV/Radio, billboard bekerjasama dengan mitra strategis (antara lain PKES).

e. Melaksanakan sosialisasi kepada berbagai asosiasi industri/Kadin/kelompok bisnis dan kepada media massa

f. Melakukan sosialisasi kepada organisasi massa (Islam) untuk mendorong kemitraan dengan perbankan syariah dalam pengelolaan aset keuangan (Muhammadiyah, Nahdatul Ulama/NU, dan lainlain).

Sebagaimana di era BI, di era Otoritas Jasa Keuangan (OJK), edukasi untuk meningkatkan pemahaman masyarakat terhadap keuangan pun mendapat perhatian yang serius termasuk pemahaman masyarakat terhadap keuangan syariah. Hal ini ditandai dengan terbitnya Surat Edaran OJK Nomor 1/SEOJK.07/2014 tentang Pelaksanaan Edukasi Dalam Rangka Meningkatkan Literasi Keuangan Kepada Konsumen dan/atau Masyarakat. Surat Edaran tersebut ditujukan kepada Direksi/ Pengurus Pelaku Usaha Jasa Keuangan, baik yang melaksanakan kegiatan usahanya secara konvensional maupun syariah. Dalam Surat Edaran tersebut disebutkan bahwa edukasi adalah penambahan pengetahuan dan kemampuan seseorang melalui teknik praktik belajar atau instruksi, dengan tujuan untuk mengingat fakta atau kondisi nyata, dengan cara memberi dorongan terhadap pengarahan diri, aktif memberikan informasi-informasi atau ide baru (OJK, 2014).

Pada gambar 1 dapat diperoleh satu gambaran suatu model edukasi yang mencerminkan perlunya kerjasama dalam edukasi perbankan syariah. Kerjasama melibatkan unsur-unsur stakeholders baik dari pihak perbankan syariah, regulator maupun masyarakat.

\section{Evaluasi}

Pada 2007 BI juga menyusun Cetak Biru Edukasi Masyarakat di Bidang Perbankan sebagai panduan dalam edukasi perbankan. Dalam cetak biru tersebut, disebutkan pola strategi edukasi masyarakat di bidang perbankan dalam jangka pendek antara lain adalah melaksanakan program edukasi untuk meningkatkan awareness terhadap kelembagaan serta produk dan jasa perbankan syariah dalam rangka meningkatkan pangsa pasar perbankan syariah (Bank Indonesia, 2007 (1)). Sementara itu, untuk memberikan kejelasan mengenai arah pada yang telah disusun akan ditetapkan tiga indikator utama edukasi, yaitu:

1). Meningkatnya awareness

2). Terwujudnya perubahan perilaku

3), Terwujudnya masyarakat yang bank minded

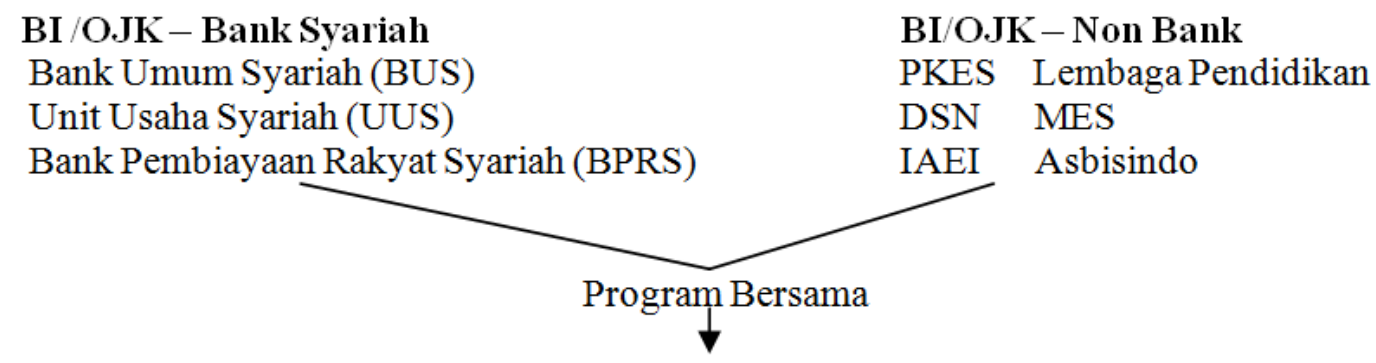

Aksi Bersama/Menyelenggarakan Events:

talkshow, seminar dan konferensi, pendekatan personal, profil industri bank syariah, pameran, creative media, website dan internet based, co branding, berita dan publisitas, brosur, iklan cetak outdoor, media sosial, media massa, media elektronik, dan buku populer

\section{Kontribusi Terhadap Pemahaman Perbankan Syariah}


Berdasarkan hal tersebut, maka evaluasi keberhasilan edukasi publik yang dapat diusulkan dalam penelitian ini dapat menggunakan indikator sebagai berikut:

1). Peningkatan awareness segmen essentially conventional terhadap perbankan syariah.

2). Hanya $40 \%$ dari segmen essentially conventional yang bersedia memindahkan rekenibgnya ke bank syariah jika menerima edukasi bank syariah. Evaluasi terhadap segemen essentially conventional adalah dengan melihat terjadinya perubahan perilaku sehingga ada kesediaan memindahkan rekeningnya atau membuka rekening di bank syariah.

\section{SIMPULAN}

Konsumen pada wilayah Jabodetabek terbagi ke dalam segmen syariah loyalis, follower, functional benefit, obligatory dan essentially conventional. Pemahaman masyarakat terhadap perbankan syariah secara umum masih rendah. Perhatian yang lebih terhadap edukasi perbankan syariah perlu diberikan kepada segmen essentially conventional. Pelaksanaan edukasi perbankan syariah harus memperhatikan aspek-aspek kognitif, emosional, estetika, spiritual dan sosial.

\section{UCAPAN TERIMA KASIH}

Terima kasih disampaikan kepada Direktorat Penelitian dan Pengabdian Masyarakat (DRPM) Kementerian Riset, Teknologi, dan Pendidikan Tinggi selaku pemberi dana melalui penelitian Hibah Penelitian Produk Terapan Tahun 2017.

\section{DAFTAR PUSTAKA}

Bachro, A. \& Supriyatni, R. (2010). Pembiayaan Bagi Hasil dalam Pembiayaan Syariah yang Berkeadilan Sebagai Salah Satu Upaya Pengembangan Bank Syariah, Sosiohumaniora, 12, (3), 250-269.

Bank Indonesia. (2007) (1). Cetak Biru Edukasi Masyarakat di Bidang Perbankan, Jakarta : Bank Indonesia.

(2007) (2). Kebijakan Akselerasi Pengembangan Perbankan Syariah 2007-2008, Jakarta : Bank Indonesia.

(2012). Direktorat Perbankan Syariah Bank Indonesia, Kajian Model Bisnis Perbankan Syariah, Jakarta : Bank Indonesia.

. (2013). Grand Strategi Pengembangan Pasar Perbankan Syariah dalam www.bi.go.id, diunduh 20 April 2013.

Daniar, A. \& Syam, N.W. (2012). Konstruksi Makna Bank Konvensional Bagi Umat Islam, Sosiohumaniora, 14, (2), 104-115.
Hirsanuddin, (2005). Kemitraan Usaha Dalam Bisnis (Studi Terhadap Pelaksanaan Perjanjian Pembiyaan Bisnis dengan Prinsip Mudharabah di Perbankan Syariah, Disertasi, Program Pascasarjana Fakultas Hukum, Universitas Indonesia.

http://ekonomisyariah.info/blog/2013/04/22/industri perbankan_syariah_gelar-expo_ib_vaganza/ Industri. Perbankan Syariah Gelar Expo iB Vaganza, diakses 1 Juni 2013.

https://www.bi.go.id/id/ekonomi-dan-keuangan-syariah/ Cetak-Biru/Contents/default.aspx. Cetak Biru Pengembangan, diakses 4 Mei 2018.

http://republika.co.id/berita/ekonomi/syariahekonomi/17/12/15/p0zzu2382-ojk-minatmasyarakat-terhadap-perbankan-syariahmeningkat, diakses 5 Mei 2018.

Rahmad. (2015). Peningkatan Efektifitas Sosialisasi Bank Syariah dalam http://rahmadpenelitimuda. blogspot.com/2012/06/peningkatan-efektifitassosialisasi.html diakses 17 April 2015.

Retallick, M.S. \& Miller, G. (2010). Teacher Preparation in Career and Technical Education: A Model for Developing and Researching Early Field Experiences. Journal of Career and Technical Education, 25, (1), 25-46.

Otoritas Jasa Keuangan. (2014). Surat Edaran OJK Nomor 1/SEOJK.07/2014 tentang Pelaksanaan Edukasi Dalam Rangka Meningkatkan Literasi Keuangan Kepada Konsumen dan/atau Masyarakat.

Setkab Republik Indonesia. (2013). Sambutan Presiden Republik Indonesia pada Pencanangan Gerakan Ekonomi Syariah (GRES!), dalam http:/www. setkab.go.id/pidato-11093-sambutan-presidenrepublik-indonesia-pada-pencanangan-gerakanekonomi-syariah-gres-jakarta-17-november-2013. html, diakses 18 Nopember 2013

Sukardi. (2004). Metodologi Penelitian Pendidikan: Kompetensi dan Praktiknya, Jakarta: Bumi Aksara.

Waluyo, B. \& Ansori. 2010. Persepsi dan Sikap Masyarakat Kampus Terhadap Bank Syariah, Studi Kasus pada Civitas Akademika Universitas Indonesia dan Politeknik Negeri Jakarta, Hasil Penelitian, UP2M Politeknik Negeri Jakarta

Waluyo,B\&Ekowati,L.(2008). PengaruhLaporanKeuangan Bank Syariah Terhadap Perilaku Pembacanya (Studi Kasus Pada Civitas Akademika Politeknik Negeri Jakarta), Jurnal Ekonomi dan Bisnis, 7,(1), 19-30.

Waluyo, B. dan Sujarwo. (2013). Sosialisasi dan Edukasi Publik Perbankan Syariah di Indonesia. Account: Jurnal Akuntansi, Keuangan dan Perbankan, 1, (1), 40-49 
Waluyo, B. \& Waluyo, Y.S. (2013). Persepsi Masyarakat Kampus Terhadap Stigma Perbankan Syariah (Studi Pada Politeknik Negeri Jakarta dan Universitas Indonesia), Perspektif, Jurnal Manajemen dan Keuangan Bisnis, 1, (1), 323-335.
Winandar, R. (2011). Evaluasi Strategi Bank Indonesia Dalam Pengembangan Perbankan Syariah Indonesia. Tesis. Program Studi Magister Manajemen, Fakultas Ekonomika dan Bisnis Universitas Gajah Mada 